\title{
Comparative Study of Strategic Management Schools (Prescriptive, Descriptive and Integrated)
}

\author{
Farid Ahamd Monib ${ }^{1,2}$, Jamaluddin Qanet ${ }^{1,2}$, Mohammad Dawod Nabeel ${ }^{2}$, Redwanullah Abdi ${ }^{3}$ \\ ${ }^{1}$ Economy Faculty, Dunya University, Kabul, Afghanistan \\ ${ }^{2}$ Faculty of Journalism, Al-Beroni University, Kapisa, Afghanistan \\ ${ }^{3}$ School of Management and Commerce, APG (Alakh Praksh Goyal) Shimla University, Shimla, India \\ Email: ^afaridmonib@gmail.com, *prof.faridmonib@au.edu.af
}

How to cite this paper: Monib, F. A., Qanet, J., Nabeel, M. D., \& Abdi, R. (2021). Comparative Study of Strategic Management Schools (Prescriptive, Descriptive and Integrated). Open Journal of Business and Management, 9, 1965-1979.

https://doi.org/10.4236/ojbm.2021.94106

Received: June 20, 2021

Accepted: July 25, 2021

Published: July 28, 2021

Copyright () 2021 by author(s) and Scientific Research Publishing Inc. This work is licensed under the Creative Commons Attribution International License (CC BY 4.0).

http://creativecommons.org/licenses/by/4.0/

\begin{abstract}
This article seeks to compare the schools of strategic management in three paradigms, especially descriptive and descriptive schools, and considers the integrated schools of strategic management as a combination of the other two types of schools. In this article, to achieve this goal, we first try to explain the concepts of strategic management, model, theory, approach, school and paradigm and schools of strategic management. Then, using the qualitative comparative research method and the type of close comparison, the researcher came to the conclusion that the schools of strategic management are not incomplete. They are complementary and it is necessary to use each of them in organizations. Then, we will compare the relationship between these concepts, especially the concepts of strategic management and strategic planning, with schools of learning and planning, and finally we will find out. The prescriptive and descriptive schools are complementary and supportive according to the integrated schools.
\end{abstract}

\section{Keywords}

Strategic Management, Paradigm, Prescriptive School, Descriptive School, Integrated School

\section{Introduction}

In general, there are three lines of thought in the field of strategy and how it is formed. A group of thinkers such as Mintzberg, Ohma and Stacey believe that strategy is an intuitive thing and the process of its formation is an art. In this thinking, strategy as an art, planning and strategic thinking are two different and 
separate categories in which planning originates from thinking. In this view, the strategic planning process leads to planning, not strategy (Agras \& Deliorman, 2014). Therefore, one should think about developing creative and effective strategies, not a logical process and method for strategic planning. According to this view, the process of forming and creating a strategy is more based on creativity and vision of the individual than a process based on specific and pre-planned plans. Another group of scientists, such as Porter, Ansoff, and Andrews, believe that the process of creating and shaping strategy is a logical and rational process that can be planned in advance (Agras \& Deliorman, 2014). Accordingly, the process of adopting a science strategy is considered. In the meantime, a group also discusses the combination of both. This group tries to combine creative and innovative views as well as analytical and quantitative views (Farahbod \& Borhaninia, 2013: pp. 1-2).

Andrews and Ansoff, both experienced professors in the field of strategic management, have proposed methods that have raised questions from experts in the field, whether the methods presented in the books of these two people and even other books that Do the schools follow, will they be applicable with the current daily changes? Some believe that in all circumstances, even in developed countries, it is not possible to implement strategic management within the framework of this school (David, 2015; Ali Ahmadi, Ali Reza and Nimroz, 2005: p. 436).

With the studies done and the study and feasibility of implementing this type of management and considering that everyone believes that strategic management is a kind of adaptive, creative, dynamic and specific management specific to the period of rapid environmental changes and sudden and unpredictable changes (Ketchen \& Short, n.d.; Agras \& Deliorman, 2014). And social, political, and cultural revolts, and finally it comes to mind, which of the schools of strategic management is better, more appropriate, and more practical in general, and whether the implementation of this type of management is different in different parts of the world (David, 2015).

One of the highlights of strategic management is whether strategy is a science or an art. I'm sure all friends will agree that both strategy and science are the answer to strategy. But it must be said that strategic management, especially the schools of strategic management, will respond better to this issue. When we have the best way of strategy, whether it is science or art or both, it can be explained in this field of management that we are familiar with the schools of strategic management (Emerson, João, \& Mário, 2014; David, 2015). Therefore, answering these questions and understanding the schools of strategic management requires familiarity with the definitions, concepts, methods and principles that have been provided so far by the technical experts of this management (Hattangadi, 2019; Neil, 2011).

Strategic management is a new concept in the field of management and therefore there are various differences in its theoretical and practical fields, its training is also associated with problems that these differences are more seriously 
discussed in the educational and scientific discussions of the world. Because the situation is significantly different in all countries, especially third world countries (Mirsapasi, 1994: p. 18). Although the purpose of this article is to analyze and compare the schools of strategic management and is primarily a theoretical and educational discussion, but this research is important because most managers and scientists of management believe that strategic management is both a science and a science. It is an art. One of the important points of this research is the real understanding of how science and art are strategic management. In this research, a reference to how strategic management enters the world as a specialized field; Then we compare the three schools of strategic management, one of which is the art of strategy, the other is scientific, and finally the schools that consider strategic management as both science and art.

The purpose of this study is to identify the most important differences and similarities of strategic management schools (prescriptive, descriptive and integrated). But for this research, sub-objectives are also considered, which are: To know about strategic management schools; Receive concepts and definitions of strategy and strategic management in different schools.

The main question of this research is what are the most important differences and similarities between the schools of strategic management? And to reach this question, the researcher does not look for the following sub-questions: Which and how are the schools of strategic management formed? What are the concepts and definitions of strategy and strategic management in different schools of strategic management? It seems that the difference between the schools of strategic management and the descriptive and descriptive schools is not limited to the art and science of strategy; Rather, prescriptive schools may emphasize the regularity of strategy and descriptive schools may emphasize adaptiveness and empiricism. Although the roots of strategy go back to antiquity; But the mental and intellectual implications of this discipline date back to the third decade of the twentieth century at Harvard University (Neil, 2011). It is believed that the schools of strategic management have offered different definitions of strategy according to the degree of acceptance of art and the scientific nature of strategy.

This research is a comparative study. To do so, almost all ten schools of strategic management thought are defined in three paradigms, compared. In this research, the method of close comparative studies has been used. The paradigms compared in this study are prescriptive paradigm, descriptive paradigm and compound paradigm. In the comparative studies of this research, the most important differences and similarities between schools and strategic management paradigms have been compared. In close comparative studies, the similarities outweigh the differences. Therefore, in this research, the most similarities and the least differences are discussed.

\section{Literature Review}

According to David (2015), Hedayati (2014), Strategic Management, the process 
of future planning of any institution that enables it not to be in a passive state when events occur and secondly to build its desired future as much as possible (Jofre, 2011; Shams, 2011: p. 62). Strategic management is a set of management decisions and actions that are formulated, implemented, controlled and evaluated according to environmental factors (Maroufi, 2006: p. 12). In another definition, strategic management is the art and science of formulating, implementing and evaluating multiple task decisions that enable the organization to achieve its long-term goals (David, 2015: p. 24; Neil, 2011). The discussed dimensions of strategic management can be adjusted to major economic, political, cyclical orientations, etc., i.e. the formulation of strategies according to environmental factors; Initial planning and design for the new organization, which can pave the way for the implementation of strategies; Finally, the exercise and exercise of power, both inside and outside the organization, is a political act (Jofre, 2011; Shams, 2011: pp. 65-66).

Mintzberg (2017), divides the schools of strategic management into two categories, the first called descriptive schools and the second descriptive schools. The first school believes in formal design and anticipation of analytical measures to act in a timely manner and in accordance with current conditions and almost the application of informal measures and the creation of the hour. Mintzberg summarizes the latter category in five schools as follows:

1) The school of innovation and practical initiative that considers the formation of strategy as an attitude process.

2) The perceptual school that considers the formation of strategy as an intellectual and mental process.

3) An environmentalist school that recognizes the application of strategy as a passive process.

4) The school of learning that introduces strategy as an adaptive empirical process, and one of the leading scholars supporting this school is Mintzberg himself.

5) The combined school which, according to Mintzberg, while considering the steps and sequence of orders in decision-making and implementation as unimportant, tries to put the findings of other schools together in a practical way (Mirsapasi, 1994: p. 19; Neil, 2011).

\subsection{Prescription Schools}

Known as the Schools of Strategic Design, researchers such as Andrews, Chandler, and Ansoff are active. In these schools, strategy is the result of an analytical and systematic process. The main issue is the adaptation and interaction of the internal conditions of the organization with the external conditions. According to these schools, strategy development is a gradual process and specific instructions are prescribed for each stage. Methods such as SWOT analysis, strategic position evaluation matrix (SPACE), internal and external matrix (IEM) and the like are considered as part of these schools (Mintzberg, 2017; Hassan Beigi, 2011: p. 134). Some scholars have provided examples of definitions of strategic man- 
agement influenced by the prescriptive school, which include:

Strategic management is the design, planning and evaluation of all actions and operations that enable the organization to map the future more accurately and clearly. Strategic management is a decision-making process that can relate the internal environment to the opportunities and threats of the external environment in such a way that the value of each of these factors in achieving the goals is well defined (Neeraja, 2018; Mintzberg, 2017). Strategy determines the way to achieve goals by considering the threats and opportunities of the external organizational environment and the resources and capabilities of the organization (Harray, 2009; Farahbod \& Borhaninia, 2013: p. 3). Strategic management is the ordering, implementation and evaluation of all actions and operations that enable the organization to map the future more accurately and clearly and achieve the goals of the organization (Mirsapasi, 1994: p. 19).

The above definitions are exactly in line with the definitions given by Andrews in his various writings, as well as the definitions of Ansoff, who are at the forefront of prescriptive strategic management (Quaye, Osei, Sarbah, \& Abrokwah, 2015; Omalaja \& Eruola, 2011). In general, the characteristics of prescriptive schools can be enumerated as follows; 1) Strategy shaping should be a conscious and controlled process; 2) The responsibility of control and awareness of the first person of the organization. This person is the true strategist of the organization and the leader of the organization, not just a manager; 3) The strategy formation model should be developed in a simple and informal way; 4) Strategies must be unique and specific to each organization; 5) The strategy should be complete and specific and, if possible, in such a way that it is kept simple; 6) The main feature of the prescriptive school is that planning, implementation and evaluation are done in a complementary but separate process (Farahbod \& Borhaninia, 2013: pp. 3, 7; Website of Marketing Companies Guide, 2014). If the strategies are designed with the above-mentioned six conditions, its implementation will be possible (Mirsapasi, 1994: p. 19). According to Mintzberg, the goal of the prescriptive school is to control the strategy process through analysis, and so what is important in this school is how the strategy is formulated, not how it appears. It is considered (Yaakob et al, 2019; Farahbod \& Borhaninia, 2013: p. 5; Maharshi Dayanand University, 2004).

\subsection{Descriptive Schools}

These schools mostly describe how to implement the strategy, believing that action should be timely and in accordance with current conditions and almost rely on the application of formal measures and the creation of the hour (Quaye, Osei, Sarbah, \& Abrokwah, 2015; Shams, 2011: p. 43). These schools seek to clarify the scope or scope of the strategy. Strategy within these schools is defined in terms of program, policy, pattern, position, or attitude. Schools of learning, empowerment, perceptual or cognitive, entrepreneurship, environmentalism and culture are considered as a subset of these schools (Yaakob et al., 2019; Farahbod \& Borhaninia, 
2013: p. 5).

The theorists of these schools are Lindblum, Quinn, Mintzberg (2017), and Gary Hamel. They reject the method of analysis in formulating strategy and point to rapid, nonlinear, and unpredictable changes in the environment (Neil, 2011). In this regard, Hamel considers his mission to make the company strategic, not strategic planning (David, 2015; Shams, 2011: p. 43; Maharshi Dayanand University, 2004). Based on descriptive schools in conditions of change, reliable evaluation and evaluation of environmental threats and opportunities is impossible and evaluation of strengths and weaknesses within the organization is unreal and affected by different perceptions of managers and therefore unreliable (Agras \& Deliorman, 2014; Farahbod \& Borhaninia, 2013: p. 5). According to these schools, not every innovative, creative, and effective strategy is necessarily the result of systematic methods. Mintzberg (2017), believes that effective strategy is a spontaneous phenomenon and emphasizes the inability of gradual processes in strategy formulation (Quaye, Osei, Sarbah, \& Abrokwah, 2015; Hassan Beigi, 2011: p. 141). Unlike prescriptive schools, in which strategy is considered a factor of restructuring, in descriptive schools, structure is slower and more difficult than strategy change, and considers strategy more than a structure that can be changed. In the context of attitude and descriptive schools, its other name is determinative schools. Factors and conditions govern the decision and, consequently, the strategy. Strategy affects them as much as it affects structure, technology and human resources.

Scholars of descriptive schools have given many definitions of it that can be expressed as follows: 1) the emphasis of strategic management is on thinking and acting in a timely manner (not having a bulky plan); 2) Strategic management is a decision-making process based on trial and error; 3) Strategic thinking and action (as opposed to tactical and operational action or thinking) focuses on the interaction and success of the whole set, not a part of the set; 4) Strategic management is an action or actions of a macro contingency and adaptation; 5) This form of thinking does not make long-term planning possible in unpredictable circumstances. 6) These schools reject the precautionary approach in strategy formulation and believe that step-by-step and predetermined processes cannot lead us to the right strategic decisions; 7) Other claims of these schools are the impossibility of defining and defining a precise and clear strategy for the future (Quaye, Osei, Sarbah, \& Abrokwah, 2015; Neil, 2011). Because organizations and environmental conditions are constantly changing; 8) In descriptive schools, there is no such thing as strategic planning, and what is considered is the formulation of strategy and its effectiveness rather than the process of strategic planning; 9) According to these schools, a strategist is someone who can make decisions at any time based on the existing conditions for the successful movement of his organization (David, 2015; Farahbod \& Borhaninia, 2013: p. 5; Maharshi Dayanand University, 2004).

As can be deduced from the above definitions, descriptive schools pay more 
attention to strategic thinking and action than strategic planning. This thinking does not make long-term planning possible in unpredictable circumstances (where the future is precisely predictable). According to this school, strategic actions are based on experimentation, and the owners of the precautionary school have tried to create special flexibility capabilities in their early models. It should be noted that prescribing a precautionary school does not mean that the weaknesses of this school have not been accepted; Rather, the advantages of each school over the other are determined by comparing their advantages and disadvantages (Ketchen \& Short, n.d.; Agras \& Deliorman, 2014). maybe it can be said; But at least in terms of human characteristics and mental strength and according to the theory of self-fulfillment prediction, wanting to be able (Quaye, Osei, Sarbah, \& Abrokwah, 2015; Mirsapasi, 1994: p. 20). The most important claim of these schools is that planning is inseparable from implementation. Therefore, the planner and the executor must be one. Such a distinction can only be made in bureaucratic/machine models, where a small number of people think at the top and a large number of people are only the executor (David, 2015; Farahbod \& Borhaninia, 2013: p. 4).

\subsection{Compiled Schools}

This school tries to bring the previous schools closer and merge them. In fact, these schools are the common chapter of the previous two schools. In these schools, attention is paid to the development of strategic thinking and its relationship with strategic planning (David, 2015; Farahbod \& Borhaninia, 2013: p. 11). On the one hand, this school is descriptive and views the organization as groups of competitors and characteristics, and on the other hand, it considers all schools as valid in their place and considers them as integrated (Quaye, Osei, Sarbah, \& Abrokwah, 2015; Shams, 2011: p. 55; Agras, \& Deliorman, 2014). The characteristics of integrated schools are: 1 ) In the framework of the attitude of these schools, while emphasizing the need for harmony and creating a balance between the strengths and weaknesses of the organization and environmental opportunities and threats, changing environmental factors and shaping the environment according to objectives and strategies; 2) While the vision, vision and values of top managers are decisive, the role of employees and organizational departments in the role of innovators and creative thinkers is inevitable; 3) In this way of thinking, macro-analyzes along with micro-analyzes are the criteria for decisions; 4) Prescription missions and ideals are explained and implemented with more realism; 5) Integrated schools recommend a far-sighted systemic-contingency approach (Quaye, Osei, Sarbah, \& Abrokwah, 2015; Ali Ahmadi, Ali Reza and Nimroz, 2008: p. 447).

In short, prescriptive schools are more concerned with how strategies should be structured and pre-planned; Not how they are necessarily formed. Descriptive schools examine each specific aspect of the strategy formation process and deal more with the problem of describing strategies than the process and method of strategy design (David, 2015; Farahbod \& Borhaninia, 2013: p. 6; Maharshi 
Dayanand University, 2004). In a brief analysis, it can be said that the experimental-adaptive school is a descriptive school, and more realistically than the prescriptive school, it deals with the issue of strategic management and, of course, with the culture of societies based on pragmatism. Every statement and belief must have a practical consequence for human beings, otherwise it has no value. However, due to the changes that have taken place in the precautionary thinking over the last two decades, the shortcomings claimed by the scholars of the opposite school have decreased, and according to what is the result of these changes and consideration The disadvantages and shortcomings of the pre-planning school and the advantages and executive capabilities of most of the adaptive experimental school are discussed. While the common chapter of these two views can be called the school of perception (Quaye, Osei, Sarbah, \& Abrokwah, 2015; Ali Ahmadi, Ali Reza and Nimroz, 2008: p. 446; Agras \& Deliorman, 2014).

According to the supporters of this school, the organization does not have a fixed form; Rather, it changes according to the internal conditions of the organization and the external conditions of the environment (Ketchen \& Short, n.d.; Agras \& Deliorman, 2014). The main aspects of these schools include the state of the organization and its environment, as well as the formulation of strategy. On the one hand, this school is descriptive and views organizations as groups of competitors, and on the other hand, it considers all schools as valid in their place (David, 2015; Hassan Beigi, 2011: p. 151). Adherents of this school are looking for a kind of integration and integration and therefore use the components and elements of different schools. This school has two aspects; One refers to the state of the organization and the external environment of the organization, which is known as shaping. Another aspect related to the strategy adoption process is expressed by the word formulation.

Some scientists have also added systematic and contingency schools to strategic management. The interpretation of the term system-contingency model is that in each country and each organization must choose a specific model and influenced by its ideals, ideologies and environmental realities (Ketchen \& Short, n.d.; Agras \& Deliorman, 2014); However, due to the wide gap between the conditions of developing and industrialized countries, the recommendation of this article for our country is the conditions for applying strategic management with an integrated view and with a greater tendency towards pre-planning thinking; Because in addition to the risk of uncertainty about the possibility of predicting the future, in order to accelerate the reduction of backwardness, foresight with greater risk is sometimes necessary. It is almost impossible; But these dangers should be welcomed with the necessary foresight in third world countries (David, 2015; Ali Ahmadi Ali Reza and Nimroz, 2008: p. 448).

In this research, the researcher tried to base on the research hypotheses; Compare the most important similarities and differences of strategic management schools in three paradigms of prescriptive, descriptive and integrated, which are as Table 1 . 
Table 1. Similarities and differences of strategic management paradigms (Monib, 2021).

\begin{tabular}{|c|c|c|c|c|c|c|c|c|c|c|}
\hline Paradigm & \multicolumn{4}{|c|}{ Prescription (precautionary) } & \multicolumn{5}{|c|}{ Descriptive (experimental-adaptive) } & $\begin{array}{l}\text { Combined } \\
\text { (descriptive } \\
\text { and } \\
\text { prescriptive) }\end{array}$ \\
\hline $\begin{array}{c}\text { The } \\
\text { state of } \\
\text { strategy } \\
\text { in the } \\
\text { paradigm }\end{array}$ & \multicolumn{4}{|c|}{ Strategies need to be routine and pre-planned. } & \multicolumn{5}{|c|}{$\begin{array}{l}\text { Strategies are described more empirically } \\
\text { and adaptively to the situation. }\end{array}$} & $\begin{array}{l}\text { Strategies } \\
\text { must be both } \\
\text { rule-based } \\
\text { and } \\
\text { pre-planned, } \\
\text { as well as } \\
\text { empirically } \\
\text { and } \\
\text { adaptively } \\
\text { described. }\end{array}$ \\
\hline $\begin{array}{l}\text { Strategy } \\
\text { indicators }\end{array}$ & \multicolumn{4}{|c|}{$\begin{array}{l}\text { Top-down planning, research method and } \\
\text { quantity-oriented, goal-oriented strategy, } \\
\text { circuit analysis strategy }\end{array}$} & \multicolumn{5}{|c|}{$\begin{array}{l}\text { Bottom-up planning, quality-oriented research method, } \\
\text { phenomenal strategy, intuitive strategy process }\end{array}$} & $\begin{array}{l}\text { Both based } \\
\text { on necessity } \\
\text { and } \\
\text { combination }\end{array}$ \\
\hline Schools & Designing & Planning & Positioning & ntrepreneurship & Cognitive & Learning & $\begin{array}{l}\text { Power- } \\
\text { oriented }\end{array}$ & Cultural & \multicolumn{2}{|c|}{1 Environmental configuration } \\
\hline $\begin{array}{l}\text { Strategy } \\
\text { concepts }\end{array}$ & $\begin{array}{c}\text { A strategy } \\
\text { is a set of } \\
\text { guidelines } \\
\text { that } \\
\text { provide a } \\
\text { vision for } \\
\text { dealing } \\
\text { with the } \\
\text { future. }\end{array}$ & $\begin{array}{l}\text { Strategy } \\
\text { means } \\
\text { program } \\
\text { to the } \\
\text { level of } \\
\text { sub- } \\
\text { programs. }\end{array}$ & $\begin{array}{l}\text { Strategy } \\
\text { means } \\
\text { strategic } \\
\text { positions } \\
\text { in the } \\
\text { economic } \\
\text { and } \\
\text { competitive } \\
\text { market. }\end{array}$ & $\begin{array}{l}\text { Strategy as a } \\
\quad \text { leader } \\
\text { and vision. }\end{array}$ & $\begin{array}{l}\text { Strategy as an } \\
\text { attitude that } \\
\text { shows how } \\
\text { the strategist } \\
\text { relates to } \\
\text { environmental } \\
\text { information. }\end{array}$ & $\begin{array}{l}\text { Strategy } \\
\text { as a } \\
\text { learning } \\
\text { model. }\end{array}$ & $\begin{array}{l}\text { Patterns } \\
\text { and } \\
\text { situations } \\
\text { and } \\
\text { political } \\
\text { aspirations. }\end{array}$ & $\begin{array}{l}\text { The } \\
\text { collective } \\
\text { perspective } \\
\text { is unique. }\end{array}$ & $\begin{array}{l}\text { Special and } \\
\text { general } \\
\text { situations. }\end{array}$ & $\begin{array}{l}\text { Everything } \\
\text { that exists in } \\
\text { other schools. }\end{array}$ \\
\hline
\end{tabular}

\section{Research Methods}

This research is descriptive in terms of type. Descriptive research is a non-empirical study that examines the relationships between variables, testing hypotheses, describing general concepts and rules, principles and theories (Kiwi, 1991). Descriptive research usually focuses on functional relationships. However, in this research, descriptive-comparative (comparative) research method has been used. Comparative research method is a research that considers the similarities and differences of conditions or consequences between large-scale variables (Nozari, 2008: p. 238). Comparative studies are usually applicable under the umbrella of external and internal studies or near and far. In this study, the researcher used the near or internal comparison research method, which emphasizes the least differences and most similarities within the field of strategic management (Flick, 2009: p. 157) (Table 2).

The strategy formulation process in each school is based on a general view that is referred to here: The school considers strategy development to be a conceptual process; But according to the school of planning, strategy formulation is a formal process. What the positioning school approves of is that the formulation 
Table 2. Compares the schools of strategic management that we refer to (Monib, 2021).

\begin{tabular}{|c|c|c|c|c|c|c|c|c|c|c|}
\hline Paradigm & \multicolumn{4}{|c|}{$\begin{array}{l}\text { Prescription (precautionary) } \\
\text { In this paradigm, strategies are described more } \\
\text { empirically and adaptively to situations }\end{array}$} & \multicolumn{5}{|c|}{$\begin{array}{l}\text { Descriptive (experimental-adaptive) } \\
\text { In this paradigm, strategies must become } \\
\text { the rule and be devised in advance }\end{array}$} & $\begin{array}{l}\text { Combined } \\
\text { (descriptive } \\
\text { and } \\
\text { prescriptive) }\end{array}$ \\
\hline $\begin{array}{c}\text { General } \\
\text { specifications }\end{array}$ & \multicolumn{4}{|c|}{$\begin{array}{l}\text { Top-down planning, research method and } \\
\text { quantity-oriented, goal-oriented strategy, } \\
\text { circuit analysis strategy }\end{array}$} & \multicolumn{5}{|c|}{$\begin{array}{l}\text { Bottom-up planning, quality-oriented research method, } \\
\text { phenomenal strategy, intuitive strategy process }\end{array}$} & $\begin{array}{c}\text { Both are } \\
\text { based on } \\
\text { contingency } \\
\text { and } \\
\text { integration }\end{array}$ \\
\hline Schools & Designing & Planning & Positioning & Entrepreneurship & Cognitive & Learning & $\begin{array}{l}\text { Power- } \\
\text { oriented }\end{array}$ & Cultural & Environmental & configuration \\
\hline $\begin{array}{l}\text { Look at the } \\
\text { concept of } \\
\text { strategy }\end{array}$ & $\begin{array}{l}\text { A strategy is } \\
\text { a set of } \\
\text { guidelines } \\
\text { that provide } \\
\text { a vision for } \\
\text { dealing with } \\
\text { the future. }\end{array}$ & $\begin{array}{l}\text { Strategy } \\
\text { means } \\
\text { program } \\
\text { to the level of } \\
\text { sub-programs. }\end{array}$ & $\begin{array}{l}\text { Strategy } \\
\text { means } \\
\text { strategic } \\
\text { positions } \\
\text { in the } \\
\text { economic } \\
\text { and } \\
\text { competitive } \\
\text { market. }\end{array}$ & $\begin{array}{l}\text { Strategy as a } \\
\text { leader and vision. }\end{array}$ & $\begin{array}{l}\text { Strategy as an } \\
\text { attitude that } \\
\text { shows how the } \\
\text { strategist } \\
\text { relates to } \\
\text { environmental } \\
\text { information. }\end{array}$ & $\begin{array}{l}\text { Strategy as } \\
\text { a learning } \\
\text { model. }\end{array}$ & $\begin{array}{l}\text { Patterns } \\
\text { and } \\
\text { situations } \\
\text { and political } \\
\text { aspirations. }\end{array}$ & $\begin{array}{l}\text { The } \\
\text { collective } \\
\text { perspective } \\
\text { is unique. }\end{array}$ & $\begin{array}{l}\text { Special and } \\
\text { general } \\
\text { situations. }\end{array}$ & $\begin{array}{l}\text { Everything } \\
\text { that exists in } \\
\text { other schools. }\end{array}$ \\
\hline Its founders & $\begin{array}{l}\text { P. Selznick } \\
\text { A. Chendlers } \\
\text { K. R. Adrews }\end{array}$ & $\begin{array}{l}\text { H. L. Ansoff } \\
\text { Peter \& } \\
\text { Lorange }\end{array}$ & $\begin{array}{l}\text { M. Porter } \\
\text { K. J. Haatenr } \\
\text { D. E. Echendel }\end{array}$ & $\begin{array}{l}\text { Mintzberg } \\
\text { P. Draker }\end{array}$ & $\begin{array}{l}\text { Khoneman } \\
\text { Turersky } \\
\text { Simon }\end{array}$ & $\begin{array}{l}\text { Lindblom } \\
\text { G. Hame } \\
\text { J. March }\end{array}$ & $\begin{array}{l}\text { GT. Allison } \\
\quad \text { G. R. } \\
\text { Salanick }\end{array}$ & $\begin{array}{l}\text { E. Rhenman } \\
\text { R. Norman }\end{array}$ & $\begin{array}{c}\text { Developers } \\
\text { of probability } \\
\text { science }\end{array}$ & $\begin{array}{l}\text { A. D. Chendler } \\
\text { H. Mintzberg } \\
\text { R. E. Miles }\end{array}$ \\
\hline $\begin{array}{l}\text { The original } \\
\text { principle and } \\
\text { origin of the } \\
\text { scientific field }\end{array}$ & $\begin{array}{l}\text { Harvard } \\
\text { University }\end{array}$ & $\begin{array}{l}\text { Urban } \\
\text { planning, } \\
\text { systems } \\
\text { theory and } \\
\text { cybernetics }\end{array}$ & $\begin{array}{c}\text { Necessities } \\
\text { (Industrial } \\
\text { Organization), } \\
\text { Military } \\
\text { Industries }\end{array}$ & $\begin{array}{l}\text { To some extent } \\
\text { economists and } \\
\text { entrepreneurs }\end{array}$ & Psychology & $\begin{array}{l}\text { Learning } \\
\text { theory and } \\
\text { disorder } \\
\text { theory in } \\
\text { mathematics }\end{array}$ & $\begin{array}{l}\text { political } \\
\text { science }\end{array}$ & $\begin{array}{l}\text { Humanities } \\
\text { and } \\
\text { Anthropology }\end{array}$ & Biology & Date \\
\hline Prosperous & $\begin{array}{c}\text { Harvard } \\
\text { University, } \\
\text { Leadership } \\
\text { Enthusiasts in } \\
\text { America }\end{array}$ & $\begin{array}{l}\text { Professional } \\
\text { Managers } \\
\text { (MBAs), } \\
\text { Consultants } \\
\text { and } \\
\text { Government } \\
\text { Officials in the } \\
\text { United States }\end{array}$ & $\begin{array}{l}\text { Planners, } \\
\text { Strategic } \\
\text { Advisers, } \\
\text { Military } \\
\text { Advisers in } \\
\text { America }\end{array}$ & $\begin{array}{l}\text { Popular media, } \\
\text { entrepreneurs }\end{array}$ & $\begin{array}{l}\text { People with a } \\
\text { penchant for } \\
\text { psychology }\end{array}$ & $\begin{array}{c}\text { People } \\
\text { interested in } \\
\text { experience, } \\
\text { adaptation } \\
\text { especially } \\
\text { in Japan }\end{array}$ & $\begin{array}{l}\text { Those who love } \\
\text { power, politics } \\
\text { and collusion, } \\
\text { especially } \\
\text { in France }\end{array}$ & $\begin{array}{l}\text { Those who } \\
\text { love the } \\
\text { spiritual and } \\
\text { collective } \\
\text { community, } \\
\text { especially in } \\
\text { Japan }\end{array}$ & $\begin{array}{l}\text { Population } \\
\text { ecologists, } \\
\text { organization } \\
\text { theorists }\end{array}$ & $\begin{array}{l}\text { It is most } \\
\text { popular in the } \\
\text { Netherlands } \\
\text { and Germany }\end{array}$ \\
\hline $\begin{array}{l}\text { Message with } \\
\text { the main } \\
\text { slogan of } \\
\text { this school }\end{array}$ & Adapt to fit & $\begin{array}{c}\text { Formalize } \\
\text { and formulate } \\
\text { programs }\end{array}$ & $\begin{array}{l}\text { Competitors } \\
\text { analysis }\end{array}$ & $\begin{array}{c}\text { Predict with } \\
\text { intuitive } \\
\text { understanding } \\
\text { and experience. } \\
\text { Imagine }\end{array}$ & Framework & learn & Grab it & $\begin{array}{l}\text { Merge and } \\
\text { integrate }\end{array}$ & Reaction & $\begin{array}{l}\text { Combine, } \\
\text { transform }\end{array}$ \\
\hline $\begin{array}{l}\text { The general } \\
\text { behavior of } \\
\text { this school }\end{array}$ & $\begin{array}{l}\text { Thinking } \\
\text { (making a } \\
\text { strategy } \\
\text { according to } \\
\text { the situation } \\
\text { inside and } \\
\text { outside) }\end{array}$ & $\begin{array}{l}\text { Plan instead } \\
\text { of adjust }\end{array}$ & $\begin{array}{l}\text { Calculation } \\
\text { instead of } \\
\text { creating or } \\
\text { committing }\end{array}$ & $\begin{array}{l}\text { Focus on the } \\
\text { vision and focus } \\
\text { less on the } \\
\text { problems }\end{array}$ & $\begin{array}{c}\text { Worried } \\
\text { (unable to } \\
\text { face others) }\end{array}$ & $\begin{array}{c}\text { Execute } \\
\text { strategy } \\
\text { Instead of } \\
\text { following, } \\
\text { set strategy } \\
\text { at all levels } \\
\text { of the } \\
\text { organization }\end{array}$ & $\begin{array}{l}\text { Save and } \\
\text { hoard, } \\
\text { formulate a } \\
\text { review } \\
\text { strategy }\end{array}$ & $\begin{array}{l}\text { Continuation } \\
\text { rather than } \\
\text { change, } \\
\text { strategy } \\
\text { formation } \\
\text { by group } \\
\text { agreement }\end{array}$ & $\begin{array}{l}\text { Surrender } \\
\text { instead of } \\
\text { confrontation, } \\
\text { the formation } \\
\text { of strategy by } \\
\text { algebra of the } \\
\text { effects of } \\
\text { external factors }\end{array}$ & $\begin{array}{l}\text { Integrate, } \\
\text { transfer, } \\
\text { put together } \\
\text { different } \\
\text { strategies } \\
\text { based on } \\
\text { different } \\
\text { situations }\end{array}$ \\
\hline $\begin{array}{l}\text { Metaphorical } \\
\text { animal }\end{array}$ & Spider & Squirrel & Blue Buffalo & the wolf & Owl & Monkey & Lion & Peacock & Ostrich & Chameleons \\
\hline $\begin{array}{l}\text { Relevant } \\
\text { sermon }\end{array}$ & $\begin{array}{l}\text { Look before } \\
\text { you go (do } \\
\text { not jump into } \\
\text { the water, } \\
\text { see your quilt } \\
\text { and stretch } \\
\text { your legs) }\end{array}$ & $\begin{array}{l}\text { The incident } \\
\text { must be } \\
\text { treated before } \\
\text { it occurs }\end{array}$ & $\begin{array}{l}\text { Nothing but } \\
\text { reality }\end{array}$ & Lead, guide & $\begin{array}{l}\text { I will see the } \\
\text { time to } \\
\text { believe it }\end{array}$ & $\begin{array}{l}\text { If you do } \\
\text { not succeed, } \\
\text { try again } \\
\text { (Ant and } \\
\text { Amir } \\
\text { Teymou) }\end{array}$ & Take care & $\begin{array}{l}\text { An apple } \\
\text { never falls } \\
\text { farther } \\
\text { from } \\
\text { the tree }\end{array}$ & it depends & $\begin{array}{l}\text { Everything } \\
\text { has a season } \\
\text { and a time }\end{array}$ \\
\hline Tools & $\begin{array}{l}\text { SWOT, LFE, } \\
\text { EFE, CPM, } \\
\text { IEM, QSPM }\end{array}$ & $\begin{array}{l}\text { SWOT, EFE, } \\
\text { IFE, IEM, } \\
\text { PIP, PCM, } \\
\text { BSG QSPM, } \\
\text { GE }\end{array}$ & $\begin{array}{c}\text { BCG, Porter } \\
\text { Five Forces, } \\
\text { Porter Value } \\
\text { Chain, Porte } \\
\text { General } \\
\text { Strategies }\end{array}$ & $\begin{array}{l}\text { Bold action, } \\
\text { bold insight }\end{array}$ & $\begin{array}{l}\text { Interpretation, } \\
\text { rationality, } \\
\text { framing }\end{array}$ & & $\begin{array}{l}\text { Bargaining, } \\
\text { conflict } \\
\text { management, } \\
\text { coalition }\end{array}$ & & & $\begin{array}{l}\text { Life cycle, } \\
\text { change and } \\
\text { transformation }\end{array}$ \\
\hline
\end{tabular}




\begin{tabular}{|c|c|c|c|c|c|c|c|c|c|c|}
\hline $\begin{array}{l}\text { The main } \\
\text { factors of } \\
\text { strategy } \\
\text { formulation }\end{array}$ & $\begin{array}{l}\text { General } \\
\text { Manager }\end{array}$ & Planners & Analysts & Leader & $\begin{array}{l}\text { Mind and } \\
\text { psyche }\end{array}$ & Learners & $\begin{array}{l}\text { Powerful } \\
\text { people }\end{array}$ & $\begin{array}{l}\text { The whole } \\
\text { organization }\end{array}$ & Environment & $\begin{array}{l}\text { Everything } \\
\text { that exists in } \\
\text { other schools }\end{array}$ \\
\hline Organization & $\begin{array}{l}\text { Regular, } \\
\text { obedient }\end{array}$ & $\begin{array}{c}\text { Regular, } \\
\text { decomposed }\end{array}$ & $\begin{array}{l}\text { Source of } \\
\text { competitive } \\
\text { advantage }\end{array}$ & $\begin{array}{c}\text { Flexible } \\
\text { and simple }\end{array}$ & Subsidiary & Flexible & $\begin{array}{c}\text { Conflicting, } \\
\text { chaotic, } \\
\text { uncontrollable }\end{array}$ & Cohesive & $\begin{array}{l}\text { Obedient, } \\
\text { simple }\end{array}$ & $\begin{array}{l}\text { Periodic } \\
\text { variable }\end{array}$ \\
\hline Leadership & $\begin{array}{l}\text { Dominant, } \\
\text { meticulous }\end{array}$ & $\begin{array}{l}\text { Sensitive to } \\
\text { procedures }\end{array}$ & $\begin{array}{l}\text { Sensitive to } \\
\text { analysis }\end{array}$ & $\begin{array}{l}\text { Dominant, } \\
\text { intuitive }\end{array}$ & $\begin{array}{c}\text { Source of } \\
\text { cognition, } \\
\text { passive or } \\
\text { creative }\end{array}$ & $\begin{array}{l}\text { Sensitive } \\
\text { to learning }\end{array}$ & $\begin{array}{l}\text { Weakness } \\
\text { of wisdom }\end{array}$ & Symbolic & $\begin{array}{l}\text { Weakness and } \\
\text { powerlessness }\end{array}$ & $\begin{array}{c}\text { Periodic } \\
\text { change factor }\end{array}$ \\
\hline
\end{tabular}

of a process strategy is imaginative and insightful; But in the school of entrepreneurship, the formulation of strategy is an evocative and insightful process. The cognitive school believes that the formulation of strategy is a mental and intellectual process; But from the school's point of view, learning to formulate a strategy is an emerging process. The power-hungry school puts forward a negotiated strategy; But based on the cultural school, formulating a strategy is a collective process. According to the environmental school, formulating a strategy is a reactionary process; However, it is based on the school of strategy formulation of the process of transformation and transformation (Hassan Beigi, 2011: pp. 153-154).

In a general summary, we refer to scientists whose definitions are influenced by prescriptive and integrated schools. David, University of Mississippi Professor; Influenced by prescriptive schools, he defines strategic management as follows: Strategic management is the ordering, implementing, and evaluating all actions and operations that enable an organization to map the future more accurately and clearly. And achieve his goals. But Ansoff, himself influenced by descriptive schools, defines strategic management as follows: Strategic management is an action or application of a macro contingency and adaptive solution. Strategic management is management based on timely thinking and action. Strategic management is a decision-making process based on experiment and experience (Hassan Beigi, 2011: p. 153).

According to the prescriptive paradigm, strategic management is a decisionmaking process that can relate the internal environment to the opportunities and threats of the external environment in a way that the value of each of these factors in achieving the goals is well defined.

In general, the characteristics of prescriptive schools can be enumerated as follows; 1) Strategy shaping should be a conscious and controlled process; 2) The responsibility of control and awareness of the first person of the organization. This person is the real strategist of the organization and the leader of the organization, not just a manager; 3) The strategy formation model should be developed in a simple and informal way; 4) Strategies must be unique and specific to each organization; 5) The strategy should be complete and specific and, if possible, in such a way that it is kept simple; 6) The main feature of the prescriptive 
school is that planning, implementation and evaluation are done in a complementary but separate process (Farahbod \& Borhaninia, 2013: p. 3); 7) If the strategies are designed with the above-mentioned six conditions, its implementation will be possible (Mirsapasi, 1994: p. 19).

The descriptive paradigm has mostly described how to implement the strategy, believing that action should be timely and in accordance with the current situation and almost rely on the application of formal measures and the creation of the hour (Shams, 2011: p. 43). These schools seek to clarify the scope or scope of the strategy. Strategy within these schools is defined in terms of program, policy, pattern, position, or attitude. Schools of learning, empowerment, perceptual or cognitive, entrepreneurship, environmentalism and culture are considered as a subset of these schools (Farahbod \& Borhaninia, 2013: p. 5).

Scientists have provided descriptive paradigms with many definitions that can be expressed as follows: 1) the emphasis of strategic management is on thinking and taking timely action (not having a bulky plan);2) Strategic management is a decision-making process based on trial and error; 3) Strategic thinking and action (as opposed to tactical and operational action or thinking) focuses on the interaction and success of the whole set, not a part of the set; 4) Strategic management is an action or actions of a macro contingency and adaptation; 5) This form of thinking does not make long-term planning possible in unpredictable circumstances. 6) These schools reject the precautionary approach in strategy formulation and believe that step-by-step and predetermined processes cannot lead us to the right strategic decisions; 7) Other claims of these schools are the impossibility of defining and defining a precise strategy for the future. Because organizations and environmental conditions are constantly changing; 8) In descriptive schools, there is no such thing as strategic planning, and what is important is the formulation of strategy and its effectiveness rather than the process of strategic planning; 9) According to these schools, a strategist is someone who can make decisions at any time based on the existing conditions for the successful movement of his organization (Farahbod \& Borhaninia, 2013: p. 5).

The integrated paradigm seeks to bring the previous schools closer together. In fact, these schools are the common chapter of the previous two schools. In these schools, attention is paid to the development of strategic thinking and its relationship with strategic planning (Farahbod \& Borhaninia, 2013: p. 11). This school is on the one hand descriptive and views the organization as groups of competitors and characteristics, and on the other hand considers all schools as valid in its place and considers them as integrated (Shams, 2011: p. 55). The characteristics of integrated schools are: 1) In the framework of the attitude of these schools, while emphasizing the need for harmony and creating a balance between the strengths and weaknesses of the organization and environmental opportunities and threats, changing environmental factors and shaping the environment according to objectives and strategies; 2 ) While the vision, vision and values of top managers are decisive, the role of employees and organizational 
departments in the role of innovators and creative thinkers is inevitable; 3) In this way of thinking, macro-analyzes along with micro-analyzes are the criteria for decisions; 4) Prescription missions and ideals are explained and implemented with more realism; 5) Integrated schools recommend a far-sighted systemic-contingency approach (Ali Ahmadi, Ali Reza and Nimroz, 2008: p. 447).

\section{Conclusion}

The strategy formulation process in each school is based on an overview, which is referred to here: The school considers strategy development as a conceptual process; but according to the school of planning, strategy formulation is a formal process. What the school of positioning approves is that the formulation of a strategy is said to be an imaginative and insightful process; but in the school of entrepreneurship, the formulation of strategy is an evocative and insightful process. The cognitive school believes that the formulation of strategy is a mental and intellectual process. But from the school's point of view, learning to formulate a strategy is an emerging process. The power-hungry school puts forward a negotiated strategy; but based on the cultural school, formulating a strategy is a collective process. According to the environmental school, formulating a strategy is a reactionary process. However, it is based on the school of strategy formulation of the process of transformation and transformation.

If the organization adopts an existential state, then creating a strategy is a process of jumping from one state to another. This plan discusses from two perspectives. The first view relates to the various dimensions of an organization that combine under certain conditions to create "states", "models" or "types". The next perspective is related to how these situations are arranged in order to determine the "stages" and life cycles of the organization. A brief look at the evolution of major currents of strategic analysis shows that there are many similarities between schools within each group; But the most important and significant school that existed in the decades before and after the Second World War and influenced both the planning of commercial and industrial companies and macro-level planning, is the school of strategic planning.

Some believe that strategic planning and basically planning and formulating strategy in organizations are questionable; but some contradict this view with the theory of limitations. Others, by modifying and flexing the above view, believe that the strategic approach and strategy-based planning have a yard cycle similar to the production yard cycle; If modern strategy has declined in the United States, it is nearing maturity in twentieth-century Europe, and perhaps in developing countries, such as ours, it is in infancy and growth or infancy (Hassan Beigi, 2011; Flick, 2009; David, 2015). A brief reference to the literature related to strategy formation provides a mental context for addressing the concepts and process of strategic management. In fact, addressing more than nine schools related to the category of strategy, the central discussion of this article, the schools of strategic management ends. 
Unfortunately, in this case, the research papers have not been very tangible. One of the important issues in this case is the existence of textbooks and case books; but there are not many articles that specifically compare the schools of strategic management.

\section{Conflicts of Interest}

The authors declare no conflicts of interest regarding the publication of this paper.

\section{References}

Agras, S., \& Deliorman, R. B. (2014). Evaluation of the Paradoxes in Strategy Formation from the Perspectives of Strategic Management Schools. European Journal of Business and Social Sciences, 3, 302-311.

http://kutuphane.marmara.edu.tr/dosya/kutuphane/form-files/382//1583403325.pdf

Ali, A., Ali, R., \& Ali, N. (2008). Comparison of Schools, Strategic Management, PrePlanning and Experimental-Adaptive. In Proceedings of 5th Student Conference on Industrial Engineering (pp. 434-448). Humanities.

David, F. R. (2015). Strategic Management (35th ed., pp. 24). P. Ali, \& M. A. Seyed (Trans.), Cultural Research Office.

Emerson, W. M., Ferreira, J. J., \& Raposo, M. L. (2014). Strategy and Strategic Management Concepts: Are They Recognised by Management Students? Business Administration and Management, 17, 43-61. http://legado.fucape.br/_public/producao cientifica/2/Strategy\%20And\%20Strategic.pdf

Farahbod, F., \& Borhaninia, R. (2013). Schools of Strategic Management (pp. 1-12). Islamic Azad University Unit.

Flick, O. (2009). An Introduction to Qualitative Research. H. Jalili, Trans., Ney Publishing.

Harray, N. (2009). The Challenge of Strategic Management and Strategic Leadership in the Case of Three New Zealand Secondary Schools. Unitec Institute of Technology. https://hdl.handle.net/10652/1297

Hassan Beigi, I. (2011). Strategic Management (1st ed., pp. 133-154). Samat Publications.

Hattangadi, V. (2019, June 17). Evaluating Mintzberg's 10 Schools of Thoughts for Strategy Formulation. Financial Express.

https://www.financialexpress.com/opinion/evaluating-mintzbergs-10-schools-of-thoug hts-for-strategy-formulation/1609541/

Hedayati, A. R. (2014). Definition of the Approach. http://rahtooshe.com/?p=2383

Jofre, S. (2011). Strategic Management: The Theory and Practice of Strategy in (Business) Organizations. DTU Management 2011 No. 1, Technical University of Denmark. https://backend.orbit.dtu.dk/ws/portalfiles/portal/5705108/rapport1.11.pdf https://orbit.dtu.dk/en/publications/strategic-management-the-theory-and-practice-ofstrategy-in-busin

Ketchen, D., \& Short, J. (n.d). Mastering Strategic Management. http://www.opentextbooks.org.hk/system/files/export/17/17062/pdf/Mastering Strateg ic Management 17062.pdf

Kiwi, R. C. (1991). Research Methods in Social Sciences (Theoretical and Practical). N. Abdolhossein, Trans., Contemporary Culture. 
Maharshi Dayanand University (2004). Strategic Management. Maharshi Dayanand University.

http://www.mdudde.net/books/Mcom/Mcom-f/strategic-management(crc)-final.pdf

Maroufi, F. (2006). Fundamentals of Strategic Management (1st ed., pp. 12-14). Mahra Publications.

Mintzberg, H. (2017). The Ten Schools of Thoughts by Henry Mintzeberg. International Journal of Latest Engineering Research and Applications, 2, 32-36. http://www.ijlera.com/papers/v2-i1/4.201701008.pdf

Mirsapasi, N. (1994). Comparison of Two Schools in Strategic Management. Tadbir Quarterly, No. 43, 18-23.

Monib, F.A. (2017). Public Relations Strategic Management. Lambert Publication.

Neeraja, M. (2018). Strategic Management. Chadalawada Ramanamma Engineering College.

https://www.studocu.com/in/document/university-of-delhi/bcom-hons/strategic-mana gement-notes-crec/8738241

Nozari, H. A. (2008). Philosophy of History, Methodology and Historiography. New Design.

Omalaja, M. A., \& Eruola, O. A. (2011). Strategic Management Theory: Concepts, Analysis and Critiques in Relation to Corporate Competitive Advantage from the ResourceBased Philosophy. Economic Analysis, 44, 59-77.

https://www.library.ien.bg.ac.rs/index.php/ea/article/view/194/190

Quaye, I., Osei, A., Sarbah, A., \& Abrokwah, E. (2015) The Applicability of the Learning School Model of Strategy Formulation (Strategy Formulation as an Emergent Process). Open Journal of Business and Management, 3, 135-154.

https://doi.org/10.4236/ojbm.2015.32014 https://www.scirp.org/pdf/OJBM 2015033116560604.pdf

Ritson, N. (2011). Strategic Management. Ventus Publishing ApS. https://www.kau.edu.sa/Files/0057862/Subjects/Strategic\%20Management\%20Book.pdf

Shams, A. H. (2011). Management of Industrial-Commercial Strategies and the Position of the Government (1st ed., pp. 20-59). Scientific Publications.

Website of Marketing Companies Guide (2014). Definition of School and Paradigm.

Yaakob, M.F.M., Musa, M.R., Habibi, A., \& Othman, R. (2019). Strategic Management and Strategic Planning in School: Is It Worth for Teachers? Academy of Strategic Management Journal, 18, 1-6.

https://www.researchgate.net/publication/333662860 STRATEGIC MANAGEMENT AND STRATEGIC PLANNING IN SCHOOL IS IT WORTH FOR TEACHERS

https://www.abacademies.org/articles/Strategic-management-and-strategic-planning-i n-school-is-it-worth-for-teachers-1939-6104-18-3-368.pdf 